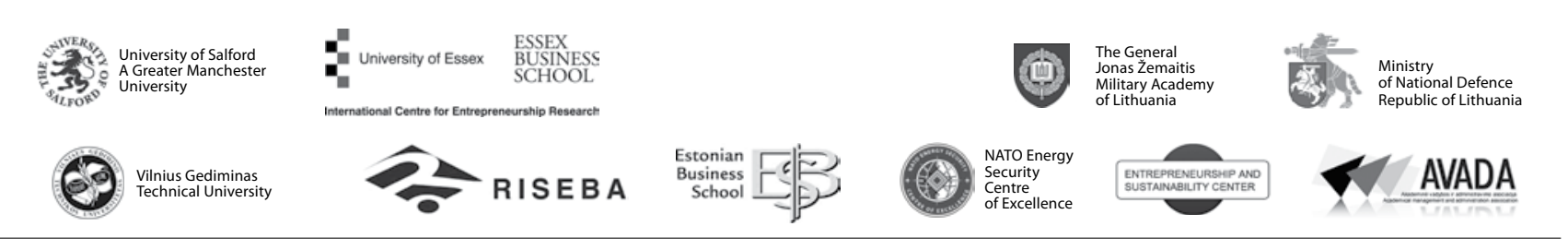

\author{
JOURNAL OF SECURITY AND SUSTAINABILITY ISSUES \\ ISSN 2029-7017 print/ISSN 2029-7025 online \\ 2017 June Volume 6 Number 4 \\ http://doi.org/10.9770/jssi.2017.6.4(11)
}

\title{
TOWARDS CONFLICTS' SETTLEMENT: DEVELOPMENT OF THE MEANING OF MEDIATION IN THE LEGAL DOCTRINE
}

\author{
Nikolajs Jefimovs \\ Daugavpils University, Vienibas Str. 13, LV-5400 Daugavpils, Latvia \\ E-mail: nikolajs.jefimovs@du.lv
}

Received 14 January 2016; accepted 25 March 2016

\begin{abstract}
The alternative methods of dispute resolution are new field of study in Latvia. In most cases procedurial issues of these methods and their real practical application are outside any legal regulation. One of these alternative dispute resolution methods is called mediation. Person, who is responsible for the management of this process, is called mediator. The meaning of this term is known from the ancient civilization times. It is useful to understand the initial comprehension of mediation in order to sucessfully implement this process in the legal system of modern society. Nevertheless the elaboration of mediation procedure asks serious evalution of possibilites in order to completely evolve basic principles of alternative dispute resolution methods in the legal system of any country. Answering on question whether it is possible to completely realize the concept of mediation, it is necessary clearly understand, what it is and how you can use the advantages of this process in real life.
\end{abstract}

Keywords: mediation, comprehension, concepts, conflict settlement

Reference to this paper should be made as follows: Jefimovs, N. 2017. Towards conflicts' settlement: development of the meaning of mediation in the legal doctrine, Journal of Security and Sustainability Issues 6(4): 665-672. http://doi.org/10.9770/jssi.2017.6.4(11)

JEL Classifications: K10, K14, K40

\section{Introduction}

The term "mediation" as a conflict resolution option the first time has been used by ancient Chinese and ancient Indian philosophers in the sixteenth century BC (Wikipedia). Similarly, the concept of mediation is used in commercial law of Phoenicia in the fourth century BC (A Short History of Mediation). Mediation application development took place in ancient Greece and ancient Rome (History of Mediation), providing possibilities for the usage of mediation in the Justinian's Digest (History of Mediation). At the same time, despite the existence of a sufficiently long history of the concept of "mediation", this term hasn't a universal definition. This is due to the wide range of forms of expression of term "mediation", as well as to differences in law-making process in various countries (The Origin of Mediation).

\section{Origin of the notion „mediation”}

The absence of common understanding of mediation causes controversy in the scientific community. There is an opinion that accurate determination of mediation is difficult to achieve (Topor, Dragomir 2012), or, due to its similarity with the other methods of dispute resolution (Teivāns-Treinovskis, Amosova 2016), mediation is difficult to define (Brown, Duggan 2012). However, the meaning of mediation is important to determine and narrow from the other cases, when the conflict is solved because of the application of other alternative dispute 
resolution methods (Girūnas, Mackevičius 2014), without going to the conventional courts (Johnson 2012).

Accurate determination of the mediation concept is an important condition for the understanding of its nature (Genn 2010). The term "mediation" is derived from the Latin word "mediationem", which means "split in the middle" (Online Etymology Dictionary). Sometimes this term is associated with the origin of the Latin word "mediare", which means "average" (Bouvier), as well as with the Latin word "medius", that means "in the middle" (Etymology of the word mediation). Often researchers of the concept of mediation associate meaning of the the word "mediation" with the Celtic word "medi", which means "of the middle" (Etymology of the word mediation). There are an assumptions, that the term "mediation" is derived from the ancient Gallic word "Mediolanon", which means "center of the territory" (Etymology of the word mediation). A more precise definition of the term "mediation" can be obtained by extracting the root "med" from the word "mediation", that means "to think" (Galletto, Mattiaccio 2011) or "help to determine" (Price 2012). In this sense, mediation can be linked to efforts to understand and help solve the problem (Bastard 2010).

The author points out, that in the modern English language word "mediation" has several meanings: 1) intervention in dispute with a view to settle the dispute; 2) intervention in the process or relationship; 3 ) persuasion; 4) arbitration (Oxford Dictionaries Online).

Merriam-Webster Encyclopedia Britannica defines mediation as 1) intermediation act or process; 2) interference between the conflicting parties for the promotion of satisfaction or compromise; 3) physical act or process of intermediation (Merriam-Webster Encyclopedia Britannica). The American Heritage Dictionary of the English Language defines mediation as 1) intermediation act, interference; 2) condition of intermediation; 3) attempt to reach a peaceful settlement or compromise between the parties of dispute through the objective interference of neutral third party (The American Heritage Dictionary 2010). Collins English Dictionary provides a detailed definition of the term "mediation": 1) act of intermediation; 2) the resolution method of any dispute, arising between the countries, engaging a third neutral and friendly country; 3 ) industrial dispute resolution method, where the third - a neutral party conduct consultations with the sides of the dispute and recommends solution of the dispute, which, however, is not binding for the parties (Collins English Dictionary 2003). Kernerman Webster's College Dictionary gives relatively short explanation of the term "mediation": act or process of intermediation between the parties in order to reach an agreement or reach a settlement of the conflict (Kernerman Webster's College Dictionary 2005).

The above insight into the term "mediation" essentially confirms, that the Latin word "mediation" has had several meanings, that aren't referred solely to the alternative resolution of conflicts, using middle man - so called mediator.

\section{Scientific definition}

Defining problem of mediation is connected with research works of social scientists. The first scientific discussion in foreign scientific literature, concerning defining issues of mediation, can be considered R. S. Woodworth's 1928 publication "Stimulus Response Theory" (Figueredo, Garcia, De Baca, Gable 2013; Woodworth 1928) as well as H. H. Hayman's 1955 book "Survey design and analysis: principles, cases and procedures" (Hyman 1955), where mediation is defined as "elaboration" (Kenny). Italy in the 1930 an Italian philosopher Antonio Gramsci in the book "Prison Notebooks", that had been translated in English in 1971, examine mediation as an ability to influence parties of conflict through the division of unequal power (influence) between them (Gramsci 1971). In Russia, the term "mediation" in legal literature appeared only in the last decade of the 20th century (Hendley 2012), although certain elements of mediation was used in the 14th century (Lisicin 2009). Need for the definition of concept of mediation in the early 20 th century was actual because of rapid development of the alternative dispute resolution methods and as a result with an inadequacy of the concept of "alternative dispute resolution procedure" to describe the processes, that contribute to the alternative resolution of conflicts.

However assessing the stage of the 20 s to 50 s of the 20th century, it is obvious, that the scientific world didn't pay special attention to the research of mediation. 
In the sixties such US researchers as Rehmus C. M., Marchant M. P., Cooper C., Raskin A. H. mainly defined mediation as a neutral third-party effect on the disputing parties in order to achieve an end to dispute (Rehmus 1965; Marchant 1994; Cooper; Raskin 1966).

In the early seventies with emergence of the Restorative Justice doctrine the United States began a gradual mediation research. R. F. Greenwald wrote a publication on alternative conflict solving between inmates and the prison administration, and offered the following definition of mediation: mediation is a process without competition, an intermediary defines the condition, according to which parties of the conflict negotiates, overcoming long existing antagonistic stereotypes and can gradually see the mutual goals (Greenwald 1978). H. G. Gadamer in the 1975 book "Truth and Method" reveals concept of mediation through the situation without values and impartiality, helping to achieve a mutually acceptable solution to the conflict (Gadamer 1975). N. E. Abrams, R. S. Berry in the 1977 publication "Mediation: a better alternative to science courts" defines mediation as "process of bringing out the facts through better communication, whether differences remained or not" (Abrams, Berry 1977). At the same time Soviet scientists in the 20-70s of the 20th century completely denied any alternative conflict resolution, because it was believed, that only state institutions were able to settle any dispute (Knjazev 2004).

In 1980, when the moral, existential, political and legal approach to the definition of mediation has been integrated with economic, psychological and philosophical approach, mediation were defined primarily as an alternative dispute resolution method, which is based on a certain ideology, but neutral intermediary participation in the scheme were considered to be the essential condition. During this period of time very popular were R. Fisher and W. Ury, which in 1981 issued the first edition of book "Getting to Yes!", where the necessity of mediation usage is stressed in the all conflict situations. Mediation concept, looking it from philosophical positions, is described by the J. Habermas in the 1981 book "Between Facts and Norms: Contributions to a Discourse Theory of Law and Democracy" (Habermas 1981). Undoubtedly, there are parallels existing with other traditional approaches to the definiton of mediation. For example, P. S. Adler defines mediation as a conflict resolution option, the aim of which is not related with the suppression of the argument, but is connected with a meaningful form and coordinated processes (Adler 1984). In the 80s Soviet scientists continued to reject any possible conflict settlement alternatives to the traditional justice (Makarov 2006), linking the potential of alternative dispute resolution among the workers only with the members of the worker's trials (Istorija mediacii). However, it is possible to meet certain legally theoretical publications about the possible settlement procedures outside the court, that designate a mediation with the term "intermediation" (Rjasencev 1984).

In the 90 s of the 20th century understanding of mediation as an alternative mean of conflict resolution strengthened its positions, expanded understanding of the potential use of mediation in the different areas, different mediation techniques and methods were defined by the practitioners. M. M. Severson and T. V. Bankston in the 1995 book "Social work and the pursuit of Justice through Mediation" defined mediation as a problem hearing and determination of the parties, involved in the dispute, offering solutions to the problem and organization of the parties' discussions, aimed at the ending of the conflict (Severson, Bankston 1995). G. P. Hawkins and C. T. Hawkins in the book "Alternative dispute resolution" link definition of mediation with the mediator, imposing him with special competences in organizing and directing the negotiation process of the parties, involved in the dispute (Hawkins, Hawkins 1993). D. E. Nolls attribute mediation to the Primal Dispute Resolution methods, offering to connect the conflict resolution process with a participation of a neutral intermediary with arbitration proceedings, which are rather similar with the traditional court proceedings (Nolls 1999). D. L. Levi in the 1997 book "The role of apology in mediation" links concept of mediation with the involved readiness to apologize to each other (Levi 1997). Relatively broad definition of mediation offers W. A. Rohne in the publication "Outside the courtroom: Mediators put a new spin on an old process": "Mediation is a forum, in which a neutral person, the mediator, provides communication between the conflict parties, in order to help them came to the terms of reconciliation or achieve understanding between them (Rohne 1998).

In the 90s of the 20th century in the Russian Federation have appeared the first scientific publications about mediation. At the same time actively progressed work with adoption of the foreign experience studies in the 
field of application of alternative dispute resolution methods. During the existence of the USSR soviet legal scientists focused mainly on the traditional functioning of the judicial system (Tejvan-Trejnovskij, Lavrinenko 2016) and its improvement, and denied existence of any systemic problems of socialist law. In the 90s of the 20th century the Russian scientists had turned to the research of problems of alternative dispute resolution methods, without denying the existence of conflict settlement problems in their national legal system.

Professor V. V. Jarkov in the 1992 monograph "Legal facts in the civil procedure implementation mechanism" mention mediation between alternative dispute resolution methods, without revealing its notion (Jarkov 1992). Honorary Lawyer of the Russian Federation A. P. Belov in the 1998 publication "Beyond economic dispute alternative settlement methods", defining mediation, indicated, that it is one of the alternative legislative practices, which is used by the conflict sides in a case, when they want to settle their conflict peacefully, as well as when parties are seeking for the establishment of their legal position in a dispute, enabling the assessment of their mutual arguments to the neutral intermediary (Belov 1998). Professor N. V. Turishova in the publication "Conciliation proceedings and the settlement in the foreign civil proceedings", studying a foreign experience in the areas of alternative dispute resolution methods, pointed out, that mediation is the reconciliation of the conflict parties, with participation by the third neutral intermediary (Turiseva 1996). Professor J. V. Kudrjavceva in the book "Judgment in the English civil procedure" pointed out, that mediation is one of the pre-litigation conflict resolution options (Kudrjavceva 1998). Professor M. I. Kiselov in the book "Comparative and international labor law" refers mediation as one of the labor dispute settlement methods with participation of neutral intermediary (Kiselev 1999). Professor S. V. Jurchenko in the 1999 publication "The question of legal nature of the contract" pay attention to mediation as one of the methods, which will make it possible to reach almost every settlement between the parties (Jurcenko 1999).

At the beginning of the 21st century US mediation researcher L. Beekman defined mediation as an informal, confidential process, in which the parties, involved in conflict, with specially trained neutral person assistance, trying to find a mutually acceptable solution to their dispute (Beekman). R. Rubinson defined mediation as an intervention in conflict or ir negotiations by a third party, that is specially empowered for that purpose and which has limited decision-making power or has no such power, but who helps conflict parties voluntarily agree on mutually acceptable conditions for the termination of their dispute (Rubinson 2004). D. O. Adetoro referred, that mediation is a usage of the third party, that is aimed at helping to those, who cant't agree to settle their conflict, or may agree on ending their conflict, but much later each of the parties suffering additional damage as a result of the conflict (Adetoro 2005). Mediation researchers the United States C. T. Autry, G. C. Reid, R. F. Hall in the publication „Mediation: Effective Resolution Of Contract Disputes” described mediation as a conflict settlement process, that necessarily requires a neutral third-party participation, which helps to agree on the terms of ending the dispute, without settling the essence of the conflict (Autry, Reid, Hall 2005). Russian Federation professor D. N. Sahabutdinova in her dissertation "Auction as a subinstitute of the contract law and legal procedure" referred, that mediation is the bargaining procedure, determining a joint work program of the involved parties, with a neutral third party participation, concluding future agreement, that is goal of the procedure (Sahabutdinova 2007). M. O. Vladimirova defined mediation as reconciliation of the parties, with a third neutral party participation, reconciliation procedure, which is implemented in accordance with the principles of voluntary participation, confidentiality, mutual respect, equality between involved parties and mediator's impartiality (Vladimirova 2014). V. O. Abolonin in the publication "Commercial Mediation in Russia: Special development vector" defined mediation as a procedure, in which a mediator with no decision-making power, using special communicative techniques, help the conflict parties to negotiate effectively, as well as help them to develop a common solution of the dispute, that satisfies the interests of both sides (Abolonin 2012). Professor D. V. Kutjukov described mediation as a conciliation process of conflicting parties, when both sides are involved in the voluntary negotiations with a neutral third party - the mediator's participation, in order to reach a mutually acceptable settlement of the conflict (Kutjukov 2011).

Latvian social science representatives were focused on the exploration of mediation, and thus the definition of mediation, at the end of the 90s of the 20th century, after the restoration of independence and following legal system's unification with democratic national rights. The author referrers, that understanding of mediation mean- 
ing between Latvian researchers is relatively uniform. For example, professor J. Bolis in the publication "Mediation: Application in the United States and prospects for Latvia" defined mediation as an extrajudicial process, where a professionally trained neutral person, who is not involved in the dispute, helps the parties themselves to find a solution in the dispute (Bolis 2011). Attorney at Law and Mediator practitioner D. Rone in the publication "Mediation: The concept and possibilities" defined mediation as a process, in which two or more persons' dispute shall be settled out of court, through one or more mediators' assistance (Rone 2006). Master of Law and attorney at Law R. Matjushina in the 2008 publication "The introduction of mediation for the settlement of commercial disputes" defined mediation as a voluntary and confidential process, in which a third, neutral party, led negotiations between conflict sides, without rights to make a decision (Matjušina 2008). German specialist A. Trossen, that practises as a mediator in Latvia, described mediation as a conflict resolution process, in which parties of the conflict with support of mediator, defines their own solution of the conflict and therefore all the parties, involved in the proceedings, are winners (Trossen). Lawyer S. Bertainis in the 2009 publication "What will be the Latvian mediation" pointed out, that mediation is a structured process, regardless of how it should be named or referred to, in which two or more involved parties, voluntarily seek to agree for a dispute settlement with the assistance of a mediator (Bērtaitis 2009). V. Ligerts defined mediation as a voluntary process, in which both sides of a dispute meet with a neutral third party (mediator), to discuss differences and reach an agreement (Ligers). Legal researcher M. Luksa in the 2012 publication "Mediation in civil proceedings: continue with the court's recommendation" referred, that mediation is a structured process of voluntary cooperation, in which involved parties shall endeavor to reach a mutually acceptable settlement of the dispute, through a cooperation with mediator (Luksa). Almost the same meaning of mediation is provided by A. Jatniece-Labucka un J. Dzanushkans "Mediation is a dispute resolution process, in which parties of the conflict with a third, neutral party or mediator, are trying to find a mutually satisfactory solution" (Jātniece-Labucka; Dzanuškāns).

Petersone defined mediation as a structured cooperation process of the conflict sides, in which a neutral person (the mediator), using a variety of techniques and professional skills, helps parties of the dispute reach a voluntary, mutually acceptable solution of the dispute (Pētersone). Practising mediator L. Bochs in the 2014 publication "Nation and mediation" referred, that mediation could be regarded as a voluntary conflict resolution process, using a mediator and through an agreement upon process to ensure each participant's interests in the conflict resolution agreement (Bočs 2014).

\section{Conclusion}

Results of the research lead to a conclusion, that development of the understanding of mediation progressed unevenly in the western and eastern countries. For the founders of ideological development of mediation and its guidelines should be considered legal researchers from the Anglo-Saxon legal family countries. At the same time it must be recognized, that mediation philosophy in the western and eastern world is based on the same basic principles of alternative dispute resolution process with the mandatory participatiom, implementation and assistance of a neutral third intermediary, who uses special techniques for the settlement of the conflict.

\section{References}

A Short History of Mediation. Available on the Internet: http://cfrmediation.com/a-short-history-of-mediation/.

Abrams, N. E.; Berry, R. S. Mediation: a better alternative to science courts. Bulletin of the Atomic Scientists. Apr1977, Vol. 33 Issue 4, p50-53. 4p., ISSN: 0096-3402

Abolonin, V. Komerceskaja mediacija v Rossii: osobij vektor razvitija. [Commercial mediation in Russia: a special vector of development]. Zakon. - 2012, No 3, p. $57-67$

Adetoro, D. O. Examining Mediation as the Opportunity Cost of Litigation: Can it be Sustained in the Long Term? Minerals \& Energy. Jun2005, Vol. 20, Issue 2, p28-35, 8p, ISSN: 1404-1049

Adler, P. S. The Balancing Act Of Mediation Training. Training \& Development Journal. Jul84, Vol. 38, Issue 7, p54. 5p., ISSN: 0041-0861 
Autry, C. T.; Reid, G. C.; Hall, R. F. Mediation: Effective Resolution Of Contract Disputes. Management Quarterly. Fall2005, Vol. 46, Issue 3, p10-25, 16p, ISSN: 0025-1860

American Psychological Association (APA): mediation. (n.d.). Online Etymology Dictionary. Available on the Internet: http://dictionary.reference.com/browse/mediation.

Bastard, B. Family mediation in France: a new profession has been established, but where are the clients? Journal of Social Welfare \& Family Law, Jun2010, Vol. 32 Issue 2, p.135-142, ISSN: 09649069

Beekman, L. Mediation Plus Options To Resolve the «Real» Problems Underlying Disputes. Available on the Internet: http://files.eric. ed.gov/fulltext/ED451644.pdf.

Belov A. Alternativnije sposobi razresenija vnesekonomiceskih sporov. [Alternative methods of noneconomics dispute resolution]. // Pravo i ekonomika, 1998, № 6

Bērtaitis, S. Kāda būs mediācija Latvijā? [What will be the mediation in Latvia?]. Dienas Bizness, 2009.g., 1pp. 21.-23

Bouvier, J. A Law Dictionary, Adapted to the Constitution and Laws of the United States. Available on the Internet: http://www.constitution.org/bouv/bouvier.htm.

Bolis, J. Mediācija: pielietojums Amerikas Savienotajās Valstīs un perspektīvas Latvijā. [Mediation: Application in the United States and prospects in Latvia]. Latvijas Zinātņu Akadēmijas vēstis, 2011., 40.lpp, ISSN: 1407-0016

Bočs, L. Nācija un mediācija. [Nation and mediation]. Published: Jurista Vārds, 20.05.2014., Nr. 20 (822)

Brown, M. E.; Duggan, N. C. Mediation As Malpractice? The Effect of California Mediation Confidentiality Statutes. Defense Counsel Journal, Jan2012, Vol. 79 Issue 1, p.94-98, ISSN: 08950016

Collins English Dictionary: Complete and Unabridged. New York: HarperCollins Publishers, 2003

Cooper, C. The Relationships Among Reading Ability, Grade Level, Syntactical Mediation In Paired-Assosiate Learning. Available on the Internet: http://files.eric.ed.gov/fulltext/ED016576.pdf

Dzanuškāns, J. Mediācija - mūsdienīga strīdu risināšanas metode? [Mediation - a modern dispute resolution method?]. Available on the Internet: <http://www.kasjauns.lv/lv/zinas/122425/mediacija--musdieniga-stridu-risinasanas-metode>

Kernerman Webster's College Dictionary. New York: Random House, K Dictionaries Ltd, 2005

Chicago Manual Style (CMS): mediation. Online Etymology Dictionary. Douglas Harper, Historian. Available on the Internet: $\mathrm{http}: / /$ dictionary.reference.com/browse/mediation

Figueredo, A. J.; Garcia, R. A.; De Baca, T. C.; Gable, J. C. Revisiting Mediation in the Social and Behavioral Sciences. Journal of Methods and Measurement in the Social Sciences, 2013, Vol.4, No.1, p.1-19

Habermas, J. Between Facts and Norms: Contributions to a Discourse Theory of Law and Democracy. Translated by William Rehg. MIT Press, 1981, 680 pp., ISBN 100745620116

Hawkins, G. P.; Hawkins, C. T. Alternate dispute resolution. American Nurseryman. 9/1/93, Vol. 178 Issue 5, p75. 5p., ISSN: 0003-0198

History of Mediation. Available on the Internet: http://www.mediationmatterssd.com/mediationmatters/history.html

Hendley, K. What If You Build It and No One Comes? The Introduction of Mediation to Russia. University of Wisconsin - Madison: Department of Political Science, 2012, Univ. of Wisconsin Legal Studies Research Paper No. 1203, pp.41

Hyman, H. H. Survey design and analysis: principles, cases and procedures. New York and Glencoe, IL: The Free Press, 1955

Etymology Dictionary. Douglas Harper, Historian. Available on the Internet: http://dictionary.reference.com/browse/mediation

Etymology of the word mediation. Available on the Internet: http://en.wikimediation.org/index.php?title=Etymology_of_the_word_mediation

Gadamer, H. G. Truth and Method. Seabury Press: First Ed. edition, 1975, pp.551, ISBN: 0816492204

Galletto, T.; Mattiaccio, R. L. Mediation in Italy: A Bridge Too Far? Dispute Resolution Journal, Aug-Oct2011, Vol. 66 Issue 3, p.78-88, ISSN: 10748105 
Genn, H. Civil mediation: a measured approach? Journal of Social Welfare \& Family Law, Jun2010, Vol.32 Issue 2, p.195-205, ISSN: 09649069

Girūnas, L. Mackevičius, J. 2014. Evaluation of frauds in public sector, Entrepreneurship and Sustainability Issues 1(3): 143-150

Gramsci, A. Selections from the Prison Notebooks of Antonio Gramsci. New York: International Publishers, 1971, pp.5-14, ISBN: 978-0717803972

Greenwald, R. F. C.R.S.: Dispute Resolution through Mediation. American Bar Association Journal. Aug78, Vol. 64 Issue 8, p1250. 5p., ISSN: 0002-7596

Kenny, D. A. Reflections on Mediation. Available on the Internet: <http://pdfskull.com/doc/11787-reections-on-mediation-david-akenny>

Kiselev M. Sravnitelnoje i mezdunarodnoje trudovoje pravo. [Comparative and international trade law]. Ucebnik dla vuzov. Moskva: Delo, 1999, p. 726

Knjazev, D. Istorija razvitija instituta mirovogo soglasenija v Rossijskom grazdanskom prave. [The history of development of the deal institute in the Russian civil law]// Sovremennije problemi grazdanskogo prava i processa: sbornik statej. Hovosibirsk, 2004, Vol.2, p.73

Kutjukov, D. Mediacija kak alternativnij sposob razresenija konfliktnih situacij. [Mediation as an alternative method of conflict resolution] // Gosudarstvo i pravo: teorija i praktika: materiali mezdunarodnoj naucnoj konferenciji — Celjabinsk: Dva komsomolca, 2011, p. $127-129$

Kudrjavceva E. Sudebnoje resenije v anglijskom grazdanskom processe. [Court decision in the English civil procedure law] // M. Gorodec, 1998, p. 143

Lisicin, V. Mediacija - universalnij spocob uregulirovanija kommerceskih sporov v Rossii: naucnij ocerk. [Mediation - a universal method of settling commercial disputes in Russia: a scientific essay]. Istorija i sovremennost. MAKS Press, 2009, p. 134, ISBN: 9785317029128

Ligers, V. Mediācija Latvijā - jauna pieeja domstarpību risināšanai. [Mediation in Latvia - a new approach to the resolution of disputes]. Available on the Internet: $<$ http://www.naibaltics.com/lv_lv/publikacijas/?doc=436>

Levi, D. L. The role of apology in mediation. New York University Law Review. Nov97, Vol. 72 Issue 5, p1165. 46p., ISSN: 0028-7881

Luksa, M. Mediācija civilprocesā: turpmāk arī ar tiesas ieteikumu. [Mediation in the civil proceedings: continue with the court's recommendation]. Available on the Internet: $<$ http://www.lvportals.lv/likumi-prakse.php?id=252542>

Johnson, L. M. The Key to Effective Mediation of Business Disputes. Dispute Resolution Journal, Nov2011-Jan2012, Vol.66 Issue 4, p.64-74, ISSN: 10748105

Makarov, N. Sag k pravovomu gosudarstvu. [Step to the legal state]. // Mediacija i pravo, 2006. №2. p. 15

Marchant, M. P. Faculty-Librarian Conflict; A Proposal for Mediation Between the Two Value Systems. Libr J, 94, 15, 2886-89, 69 Sep 1., Journal Code: CIJOCT1969

Matjušina, R. Mediācijas ieviešana komercstrīdu risināšanā. [The introduction of mediation in solving of commercial disputes]. Published: Jurista Vārds, 19.02.2008., Nr. 7 (512)

Merriam-Webster Encyclopedia Britannica. Available on the Internet: http:/www.merriam-webster.com/dictionary/mediation

Mediation. Available on the Internet: http://en.wikipedia.org/wiki/Mediation

Modern Language Association (MLA): „mediation” Online Etymology Dictionary. Douglas Harper, Historian. 09 Oct. 2014. Available on the Internet: http://dictionary.reference.com/browse/mediation

Nolls, D. E. Primary dispute resolution is first choice in conflict mediation. Business Journal Serving Fresno \& the Central San Joaquin Valley. 10/18/99, Issue 322526, pp6, ISSN: 1079-7394

Istorija mediacii. [History of mediation]. Available on the Internet: http://mediator14.ru/istoriya_mediacii.html

Jarkov V. Juridiceskije fakti v mehanizme realizacii norm grazdanskogo processualnogo prava. [Legal facts in the mechanism of realization of civil procedure law]. Izdatelstvo Sverdlovskogo juridiceskogo instituta, Jekaterinburg, 1992, p.523 
Jātniece-Labucka, A. Mediācija - palīgs konfliktu risināšanā. [Mediation - help in conflict resolution]. Available on the Internet: http:// apollo.tvnet.lv/zinas/mediacija-paligs-konfliktu-risinasana/549104

Jurcenko, S. K voprosu o juridiceskoj prirode mirovogo soglasenija. [On the question of the legal nature of the settlement agreement]. // Juridiceskij vestnik. Rostov na Donu, 1999, Vol.1, p. 81

Pētersone, Z. Tiesas atvasinātā mediācijas modeḷa ieviešana civiltiesisku strīdu risināšanā Latvijā. [Elaboration of court annexed mediation in the resolution of civil disputes in Latvia]. Available on the Internet: http://www.ur.gov.lv/faili/Z.Petersone_AT_biletens.pdf

Price, N. I. Binding Arbitration, Voluntary Trial Resolution, and Med-arb Proceedings in Family Law. Florida Bar Journal, Nov2012, Vol. 86 Issue 9, p.48-52, ISSN: 00153915

Rjasencev, V. Mirovije sdelki (soglasenija). [Peace agreements (deals)]. // Socialisticeskaja zakonnostj, Moskva, 1984, Vol.12, p. 26

Raskin, A. H. Making Strikes Obsolete. Atlantic (01606506). Jun1966, Vol. 217 Issue 6, p47. 6p., ISSN: 01606506

Rehmus, C. M. The mediation of industrial conflict. Journal of Conflict Resolution. Mar65, Vol. 9 Issue 1, p118. 9p., ISSN: 0022-0027

Rohne, W. A. Outside the courtroom: Mediators put a new spin on an old process. Business Press. 01/09/98, Vol. 10 Issue 37, p24. 2p., ISSN: $1045-8697$

Rone, D. Mediācija: Jēdziens un iespējas. [Mediation: The concept and possibilities]. Published: Jurista Vārds, 14.03.2006., Nr. 11 (414)

Rubinson, R. Client Counseling, Mediation, and Alternative Narratives Of Dispute Resolution. Clinical Law Review. Spring2004, Vol. 10 Issue 2, p833-874. 42p, ISSN: 1079-1159

Oxford Dictionaries Online (Word English). Available on the Internet: http://www.oxforddictionaries.com/definition/english/mediation

Sahabutdinova, D. Torgi kak subinstitut dogovornogo prava i juridiceskaja procedura. [Trade as an subinstitute of contract law and legal procedure]. Avtoreferat. Dissertacija kandidata juridiceskih nauk, Kazanj, 2007, p. 22

Severson, M. M.; Bankston, T. V. Social Work and the Pursuit of Justice through Mediation. Social Work. Sep95, Vol. 40 Issue 5, p683691. 9p., ISSN: 0037-8046

Teivāns-Treinovskis J., Amosova J. 2016. Some aspects of criminal environment impact on sustainable entrepreneurship activities, Entrepreneurship and Sustainability Issues 4(1): 17-24 http://dx.doi.org/10.9770/jesi.2016.4.1(2)

Tejvan-Trejnovskij, J.; Lavrinenko, O. Ocenka socialnih faktorov i uslovij deviantnogo povedenija v sovremennom obsestve. [Evaluation of social factors and conditions of deviant behavior in the modern society]. Kriminologiceskij zurnal Bajkalskogo gosudarstvennogo universiteta ekonomiki i prava. — 2016., Vol.10, № 1., p. 73-81

The American Heritage Dictionary of the English Language, Fourth Edition. Boston: Houghton Mifflin, 2000

The Origin of Mediation. Available on the Internet: $<$ http://www.uiowa.edu/ cyberlaw/elp00/Evan/mediation/origin.html $>$

Trossen, A. Mediācija - par „mediācijas” jēdzienu Latvijā Valodnieciskie aspekti. [Mediation - for the notion of „mediation” in Latvia Linguistic aspects]. Available on the Internet: $<$ http://www.mediacija.lv/?download=mediacija_lv.pdf $>$

Topor, R.; Dragomir, C. B. Mediation As An Alternative To Conflict Settlement. Contemporary Readings in Law \& Social Justice, 2012, Vol. 4 Issue 1, p.392-397, ISSN: 19489137

Turiseva N. Primiritelnije proceduri i mirovoje soglasenije v grazdanskom processe zarubeznih stran. [The conciliation and settlement proceedings in the civil law of foreign countries].//Vestnik Moskovskogo universiteta. - Moskva: Izdatelstvo Moskovskogo universiteta, 1996, № 3, p. 74-84

Woodworth, R. S. Dynamic psychology. In C. Murchison, (Ed.), Psychologies of 1925. Worcester, MA: Clark University Press, 1928, p.111-126

Vladimirova, M. Mediativnoje soglasenije v sisteme Grazdansko-pravovogo regulirovanija. [Mediation agreement in the system of civil law regulation]. Dissertacija na soiskanije ucenoj stepeni kandidata juridiceskih nauk. Available on the Internet: http://shelly.kpfu.ru/eksu/docs/DISSERTATION/29.pdf

Nikolajs Jefimovs is a Lecturer, Ph.D. candidate, Head of the Department of Economics and Sociology of the Faculty of Social Sciences of Daugavpils University. Research interests: commercial law, alternative dispute resolution methods, tort law. 